University of Michigan Law School

University of Michigan Law School Scholarship Repository

Law \& Economics Working Papers

10-1-2015

\title{
Amending China's Insider Trading Prohibition - An Immodest Proposal
}

\author{
Nicholas C. Howson \\ University of Michigan Law School, nhowson@umich.edu
}

Follow this and additional works at: https://repository.law.umich.edu/law_econ_current

Part of the International Trade Law Commons, and the Securities Law Commons

\section{Working Paper Citation}

Howson, Nicholas C., "Amending China's Insider Trading Prohibition - An Immodest Proposal" (2015). Law \& Economics Working Papers. 118.

https://repository.law.umich.edu/law_econ_current/118

This Article is brought to you for free and open access by University of Michigan Law School Scholarship Repository. It has been accepted for inclusion in Law \& Economics Working Papers by an authorized administrator of University of Michigan Law School Scholarship Repository. For more information, please contact mlaw.repository@umich.edu. 


\title{
AMENDING CHINA'S INSIDER TRADING PROHIBITION - AN IMMODEST PROPOSAL
}

\author{
Commercial Law Research Center, Tsinghua University \\ $21^{\text {st }}$ Century Commercial Law Forum $15^{\text {th }}$ Annual International Conference \\ "Modernization of the Legal Framework for the Capital Markets" \\ October 31 - November 1, 2015 \\ Nicholas Calcina Howson, \\ University of Michigan Law School \\ October 2, 2015
}

\section{Introduction}

The People's Republic of China ("PRC" or "China") is in the process of amending the 2006 PRC Securities Law. At the time of writing of this paper -- or early October 2015 -- a first draft of the new PRC Securities Law has not yet been released publicly by China's National People’s Congress (“NPC”), probably because of the market turbulence experienced on Chinese exchanges commencing in July 2015 and the extraordinary remedies undertaken by the Chinese government in response. ${ }^{1}$

Nonetheless, the amendment process continues, and so in connection with that process this paper sets forth a detailed critique of the statute and administrative law-based insider trading prohibition and enforcement regime currently in effect in the PRC, and then a concrete suggestion for the ways in which the new Securities Law (and related administrative regulation) can - and I argue, must -- be changed to create a more coherent and effective system for enforcement against this particularly harmful kind of market manipulation.

$1 \quad$ See a decidedly negative U.S. Congress appraisal of the PRC government response in the aftermath of the Shanghai Exchange collapse at Nargiza Salidjanova, China's Stock Market Collapse and Government's Response, U.S.-CHINA ECONOMIC AND SECURITY REVIEW COMMISSION ISSUE BRIEF, July 13, 2015, available at http://origin.www.uscc.gov/sites/default/files/Research/China\%E2\%80\%99s\%20Stock\% 20Market\%20Collapse\%20and\%20Government\%E2\%80\%99s\%20Response.pdf (last visited October 2, 2015). 
The domestic capital markets of the PRC have come a very long way in over two decades. With an initial market capitalization of just US $\$ 2$ billion in $1991,{ }^{2}$ by the end of 2014 the aggregate market capitalization of the almost 3,000 issuers listed on the Shanghai and Shenzhen Stock Exchanges (for mid-June 2015, 1,062 on the Shanghai Stock Exchange and 1,709 on the Shenzhen Stock Exchange) exceeded US\$ 3.7 trillion, a figure that excludes the market capitalization of PRC-domiciled or offshore-domiciled but PRC-controlled issuers listing on foreign exchanges. ${ }^{3}$

Notwithstanding this impressive expansion of domestic Exchanges and Chinese issuer participation in the global capital markets, the building and staffing of a securities regulatory system from scratch, and the rise of a relatively autonomous Chinese financial press, the Chinese markets continue to experience volatility and some significant level of dysfunction. One of the widely acknowledged problems is securities fraud, specifically insider trading, which has been pervasive in the Chinese markets since the establishment of the Shanghai and Shenzhen Exchanges in 1990-91. ${ }^{4}$ Insider trading takes many forms in the PRC. Certainly the classic situation - where insiders use non-public material information from and regarding their own company to trade in the stock of that company prior to an announcement affecting the market price of that company's securities - occurs very frequently. The case against insiders at Zhejiang Hangxiao Steel Structure Co., Ltd. is an example. In the period after a March 2007 announcement of a large infrastructure contract won by the firm in Angola, the company's stock rose 150\%. Insiders who purchased before the announcement and sold afterwards were to said to have profited by over US\$ 5 million. The big Angola contract proved to be fictitious, causing a huge price slump, but only after the insiders had dumped their pre-announcement purchases at the

2 Or 10.8 billion renminbi yuan ("RMB”) at the official 1991 RMB:US\$ exchange rate of 5.32:1. See Feng Wei, The Shanghai and Shenzhen Exchanges: Business Operation, Governance Structure and Regulatory Function (Asian Development Bank, 2000), at 332 (Table 20-1), available at: http://www.adb.org/documents/books/demutualization_stock_exchanges/chapter_20.pdf (last visited October 2, 2015).

3 See The World Bank IBRD-IDA, Market Capitalization of Listed Companies, available at: http://data.worldbank.org/indicator/CM.MKT.LCAP.CD (last visited October 2, 2015).

$4 \quad$ See Ling Huawei, Qiao Xiaohui, Fu Tao \& Hu Runfeng, Neimu Jiaoyi “Wenyi” [The Insider Trading “Plague”], 186 CAIJING, May 28, 2007, at 66-69 (hereinafter, “Insider Trading Plague”); and Shen Han, A Comparative Study of Insider Trading Regulation Enforcement in the U.S. and China, 9 J. Bus. \& Sec. L. 41, 56-60 (2007). 
high end. ${ }^{5}$ At the same time, a good deal of the activity commonly understood or reported in the Chinese and foreign media as "insider trading" in China is more closely akin to securities trading manipulation by what the Chinese idiom broadly labels “[casino] dealers” (zhuangjia). For instance, "front running” by "rat-cellars" (laoshucang) - where mutual fund managers purchase the stock of an issuer before the fund they direct makes purchases of the same stock (triggering a price rise in the stock) is also said infect the high volume domestic securities fund industry. A variant of this is a common breaching of the state-private gap in China, where non-insider private fund managers are tipped by non-insider state-owned mutual funds that they about to purchase a given issuer's stock, with an inevitable price rise upon the large state mutual funds purchase becoming known (and the state tipper and private tippee splitting the extraordinary profits). ${ }^{6}$ Accordingly, administrative enforcement actions and even criminal prosecutions for this kind of activity are effected pursuant to statutory prohibitions on "securities trading manipulation", and not "insider trading”.

At the same time, enforcement against insider trading has been anemic. One author reviewing the period between 2002 and the end of 2006, or the period prior to the issuance of what this paper calls the "2007 Insider Trading Guidance Provisions", notes the application of administrative sanctions by the China Securities Regulatory Commission (“CSRC”) in 196 cases of securities fraud, only one of which (in 2004) relates to insider trading. ${ }^{7}$ A review of the year in securities regulation for 2009 by Shanghai Stock Exchange officials ${ }^{8}$ listed only six completed enforcement actions, but also noted wide press coverage of four other insider trading scandals involving government officials straddling political and economic power. Likewise, a close review

$5 \quad$ See Insider Trading Plague, supra note 3, at 67. For similar breaches see also the Lin Shiquan and Liu Yang China Securities Regulatory Commission enforcement decisions infra.

See Gady Epstein, “Market Maker,” Forbes, Jan. 28, 2008, available at: http://www.forbes.com/global/2008/0128/050.html (last visited October 2, 2015).

See Han, supra note 3, at 57. See also Benjamin L. Liebman and Curtis J. Milhaupt, Reputational Sanctions in China’s Securities Market, 108 Colum. L. Rev. 929, 942 (2010) (for 2001-2006: "the number of [CSRC] sanctions seems rather modest given the ubiquity and severity of the problems with...insider trading... in China's stock markets.”)

See Wu Weiying \& Pu Lifen, 2009 Nian Zhongguo Zhengquan Fazhi Pingshu [2009 China Securities Rule of Law Commentary], 2 Zhengquan Fayuan [Securities Landscape] 361, 373-4 (2010). 
of publicly announced enforcement decisions ${ }^{9}$ by the CSRC shows few that are related to insider trading, and invariably only with respect to very minor actors.

The reasons for this weak enforcement record are well-known in China, and include: regulatory resource constraints; low levels of investigatory sophistication and deficient technical means; difficulties in contemporaneous detection and obtaining evidence; ${ }^{10}$ the regulator's inability to act as a civil action plaintiff (and thus extract information and/or settlements from market participants); constraints on the private civil action applicable across China's corporate law and securities law regimes; the uneven competence, autonomy and independence of China's judiciary; and - of overwhelming importance in the Chinese context - the political and economic power of some of the most flagrant violators, whether individuals or institutions. Some Chinese analysts even point to a conflict in the role of China's securities regulator, the CSRC: tasked on one side with the protection of investors and market transparency, and on the other side “... provid[ing] the [state-owned enterprises] with preferential access to the financial resources of the capital market for the best interests of the government; ...". ${ }^{11}$ Less acknowledged as a reason for weak or non-existent enforcement of the insider trading prohibition in the PRC is the subject of this paper - the unworkable architecture of the statutory prohibition against insider trading embedded in the 2006 PRC Securities Law, which has presented serious obstacles to both civil (the CSRC) and criminal (the People's Procuratorate) enforcement authorities by needlessly narrowing the scope of insider trading liability, and caused the CSRC, at least in the civil sphere, to act illegally and ultra vires with respect to many of the insider trading prohibitions it does pursue.

Whatever the cluster of reasons for it, lackluster enforcement against insider trading in China can fuel a vicious circle: obstacles to robust enforcement can ensure that the costs of insider trading are minimal or non-existent, especially when compared to the benefits on offer, which in turn only encourages further insider trading in the Chinese markets. Accordingly, this paper suggests a wholesale renovation of the PRC Securities

$9 \quad$ Posted continually at: http://www.csrc.gov.cn/pub/zjhpublic/index.htm?channel=3300/3313 (last visited October 2, 2015).

10 "With respect to the investigation of insider trading, [we] face two issues: difficulties in obtaining evidence and recognition..." May 2007 statement by a CSRC No. 1 Enforcement Department official), Insider Trading Plague, supra note 3, at 66.

11 Han, supra note 3, at 58 (pointing to the "quota" system discontinued more than a decade ago, and the continued presence of poorly-performing state-owned enterprises listed on China's domestic capital markets). This author does not concur with Han Shen's notion of a conflicted CSRC, a view informed by almost 20 years of interaction with the CSRC and its officers. 
Law's statutory architecture for the prohibition against insider trading so as to at least provide the basis for better enforcement against such market manipulation where it can be identified.

In this paper, I proceed as follows. In Section II, I describe the statutory and administrative law norms currently governing insider trading in China. In Section III, I provide a detailed critique of the current regime, being careful to distinguish the formal, statutory, scheme on one hand, and the wholly conflicting agency scheme imposed by the CSRC on the other. In Section IV, I detail how the insider trading prohibition is being enforced pursuant to the dysfunctional scheme detailed in Section III. Sections III and IV are designed to justify my case for wholesale amendment of the insider trading prohibition in any amended PRC Securities Law. Finally, in Section V, I urge a solution to the present dysfunction, and a way forward so that China can achieve a coherent and effective insider trading regime under the revised statute. 


\section{Legal and Regulatory Norms for Insider Trading in the PRC}

The legal and regulatory norms governing insider trading have developed quickly in the PRC, and concurrent with (or sometimes even before) the formal, legal, establishment of the PRC's domestic capital markets and stock exchanges. With the establishment of China's first post-1949 exchanges, the governments of Shanghai (on November 27, 1990) and Shenzhen (on May 15, 1991) promulgated municipal-level "measures" that explicitly prohibited "insider trading” (neimu jiaoyi). ${ }^{12}$ In April 1993, the State Council Securities Commission ("SCSC") — the State Council department originally above the newly-established CSRC—promulgated the first national regulation concerning securities issuance and trading, the Provisional Regulations on the Administration of Stock Issuance and Trading ("SCSC Issuance and Trading Regulations") which also explicitly prohibited "insider trading”. That prohibition was echoed in the September 1993 Provisional Measures on Prohibiting Securities Fraud Behavior issued by the SCSC ("SCSC Securities Fraud Measures"). In October 1997, the NPC amended the Criminal Law to include the crime of "insider trading", but without any elaboration on the elements of this new crime (other than heightened mens rea-type requirements which work across the Criminal Law).

Only in 1999, with passage of the PRC’s first Securities Law was insider trading extensively described and prohibited in a non-criminal "law", a formulation largely carried over into the revised Securities Law effective on January 1, 2006 ("2006 PRC Securities Law”). The 2006 PRC Securities Law also contains related prohibitions on "short swing trading" and "manipulative securities trading."13 The short swing profits rule is modeled on the U.S. Securities Exchange Act of 1934, Section 16(b), and forces directors, supervisory board members, senior management, and substantial shareholders (5\% or above) to disgorge to the corporation profits arising from trading within a six month window. There are no scienter requirements or affirmative defenses under Chinese law for breach of the short swing trading prohibition. Company directors also have direct personal liability for any short swing trading. Interestingly, if the company

12 See Article 39 of the November 27, 1990 Shanghaishi Zhengquan Jiaoyi Guanli Banfa [Shanghai Municipal Measures on the Administration of Securities Trading], and Article 43 of the May 15, 1991 Shenzhenshi Gupiao Faxing Yü Jiaoyi Guanli Zanxing Banfa [Shenzhen Municipal Interim Measures on the Administration of Stock Issuance and Trading]. The Chinese "neimu jiaoyi” for "insider trading” is a neologism that first entered China's regulatory lexicon in the October 1990 Provisional Measures on the Administration of Securities Companies (Zhengquan Gongsi Guanli Zanxing Banfa).

132006 PRC Securities Law, arts. 47 (short swing trading) and 77 (manipulative securities trading). 
board does not seek such disgorgement, even after shareholder demand, the shareholders have a legal right to implement a kind of ad hoc derivative action, and sue for disgorgement "in the name of the company." (This is not to be confused with the PRC's corporate derivative action, also established in the 2006 PRC Company Law.)

On March 3, 2007, the CSRC conceived an internal "guidance document" (zhidaoxing wenjian) on the 2006 PRC Securities Law statutory prohibition on insider trading, the (Provisional) Guide for the Recognition and Confirmation of Insider Trading Behavior in the Securities Markets ("Insider Trading Guidance Provisions"). ${ }^{14}$ The Insider Trading Guidance Provisions by their own terms are not "public" understood as a term of art under Chinese legislative and rule-making practice, ${ }^{15}$ they are not posted on the CSRC website, and are not included in any form of legislative or regulatory gazette, and therefore are not norms of which market participants have any formal notice. Moreover, they are not a species of any of the legally enforceable legal-regulatory norms permitted in the Chinese system. Instead, they are only non-legal and non-regulatory guidance directed to CSRC staff, subordinate (local-level) securities regulatory bodies, and the Shanghai and Shenzhen Stock Exchanges regarding the application of law and the implementation of administrative enforcement.

Finally, on May 22, 2012 the Supreme People’s Court and the Supreme People's Procuratorate of the PRC jointly released an "Explanation" governing the enforcement of China's statutory insider trading prohibition, but only with respect to criminal prosecutions (“Criminal Enforcement Explanation”). ${ }^{16}$ “Zhengquan Shichang Caozong Xingwei Rending Zhiyin (Shixing)" Ji “Zhengquan Shichang Neimu Jiaoyi Xingwei Rending Zhiyin (Shixing)” De Tongzhi [Notice of the CSRC Regarding the Printing and Distribution of the "(Provisional) Guide for the Recognition and Confirmation of Manipulative Behavior in the Securities Markets” and the "(Provisional) Guide for the Recognition and Confirmation of Insider Trading Behavior in the Securities Markets"] (not promulgated but distributed internally by the CSRC, Mar. 27, 2007), available at http://vip.chinalawinfo.com/NewLaw2002/SLC/slc.asp?db=chl\&gid=144622 (a CSRC notice which distributes guidance provisions for both insider trading and manipulative securities trading (the latter actionable under Article 77 of the 2006 PRC Securities Law)) (last visited October 2, 2015).

15 They are, however, widely available, for instance on the subscriber on-line collection of Chinese laws and regulations ChinaLawInfo, available at: http://www.chinalawinfo.com.

$16 \quad$ Zuigao Renmin Fayuan, Zuigao Renmin Jianchayuan Guanyu Banli Neimu Jiaoyi, Xielu Neimu Xinxi Xingshi Anjian Juti Yingyong Falü Ruogan Wenti De 


\section{III.Insider Trading Regime(s)}

China's present insider trading regulatory regime is plagued by contradictions which arise in two contexts: (i) within the formal provisions of the Securities Law itself, and (ii) as between the system articulated in the statute, on one hand, and as articulated and enforced via agency action of dubious legality, on the other. The latter conflict, between the 2006 PRC Securities Law regime and administrative enforcement under the 2007 Insider Trading Guidance Provisions which cuts the insider trading breach out of a whole new cloth, is the more pronounced - a problem implicitly recognized with the release of the Criminal Enforcement Explanation in May 2012, which attempts to draw at least criminal enforcement practice back into the bounds of the statutory scheme. As I will describe below, this second, non-law based, structure authorizes enforcement of insider trading liability against mere possessors of non-public, material, information who happen to trade securities during an ex post determined price sensitive period. The 2006 PRC Securities Law, conversely, describes something closer to (what U.S. jurisprudence calls) a "classical" or fiduciary duty-based theory of insider trading liability alongside a separate "misappropriation" type basis. I have argued that the 2007 Insider Trading Guidance Provisions are void and unenforceable, and subject to legal challenge on their face or as applied. ${ }^{17}$ Notwithstanding, because the CSRC enforces insider trading law in China pursuant to both sets of norms, in this paper I examine the entirety of the PRC insider trading prohibition derived from both the 2006 Securities Law and the 2007 Insider Trading Guidance Provisions so as to critique the regime, but also identify the way forward for possible amendment of the PRC Securities Law.

Jieshi [Supreme People’s Court, Supreme People’s Procuratorate Explanation Regarding Certain Specific Law Application Issues in the Handling of Criminal Cases of Insider Trading and the Communication of Inside Information] (passed by the Sup. People's Ct. Adjudication Comm. Oct. 31, 2011 and the Supreme People’s Procuratorate Feb. 27, 2012, issued May 22, 2012), available at http://www.court.gov.cn/qwfb/sjfs/201205/t20120522_177170 (last visited October 2, 2015).

17 See Nicholas Calcina Howson, Enforcement Without Foundation? Insider Trading and China's Administrative Law Crisis, 60 Am. J. Comp. L. 955 (2012) (hereinafter Enforcement Without Foundation). 


\section{a. The Statutory Scheme}

The 2006 PRC Securities Law addresses insider trading at eight places. ${ }^{18}$ In U.S. jurisprudential terms, the regime introduced in the 2006 statute rejects the so-called "equal access" theory while adhering to the Cady, Roberts/Chiarella line (but with defendants identified in the Securities Law or an authorized regulatory enactment), and adding an $O^{\prime} H a g a n-l i k e$ misappropriation basis.

Article 73 of the Securities Law prohibits (i) "persons with knowledge of inside information" and (ii) those "who have illegally procured inside information," from "using" inside information to engage in securities trading activities. On a first view, the 2006 PRC Securities Law rejects the confines of a U.S.-style "classical” theory by broadening the scope of defendants from status insiders to those who simply have knowledge of inside information. For scholars familiar with U.S. jurisprudence, this regime initially looks like the SEC $v$. Texas Gulf Sulphur ${ }^{19}$ equal access theory expansion of Cady, Roberts \& Co., ${ }^{20}$ which extended insider trading liability from corporate insiders to anyone in possession of material, non-public, information. (Texas Gulf Sulphur was subsequently cut back to the "classical" or fiduciary duty-based theory in Chiarella $v$. United States, ${ }^{21}$ so that liability was narrowed to those in breach of a fiduciary or special relationship of trust and confidence with the trading counterparty). ${ }^{22}$ If this initial reading would hold, the 2006 PRC Securities Law would have represented a significant departure from the earliest iterations of insider trading law in China, which addressed only the actions of formal status insiders in the style of Cady, Roberts. ${ }^{23}$

18 See 2006 PRC Securities Law, arts. 5 (basic prohibition against insider trading), 47 (short-swing trading by insiders), 73-76 (elaborated provisions on insider trading, analyzed here), 180 (power of CSRC to stop trading in suspect securities), and 202 (administrative penalties and measures). Criminal prosecution for the established crime of insider trading (at Article 180 of the PRC Criminal Law) is explicitly authorized at Article 231, while civil damages (and, perhaps, a private claim in damages) are given a legal basis in the final clause of Article 76.

19 SEC v. Texas Gulf Sulphur, 401 F.2d 833 (2d Cir. 1968), cert. denied 394 U.S. 976 (1969).

20 Cady, Roberts \& Co., 40 S.E.C. 907 (1961).

$21 \quad$ Chiarella v. United States, 445 U.S. 222 (1980).

22 Outside of the tender offer context, where the equal access theory lives on in the U.S. Securities Exchange Commission's Securities and Exchange Act of 1934 Rule 14e-3, 17 C.F.R. § 240.14e-3.

23 See Article 81 of the SCSC Issuance and Trading Regulations, and Article 5 of the SCSC Securities Fraud Measures. 
On closer inspection, however, the 2006 statute does no such thing, for Article 74 of the 2006 PRC Securities Law narrows the scope of possible defendants to "include" (baokuo) a roster of traditional company, market and regulatory insiders, and other persons stipulated in regulation by the CSRC. Those statutory persons with knowledge of insider information are: directors, supervisory board members, and senior managers of the issuer; $5 \%$ or more shareholders of the company and its/their directors, supervisory board members and senior managers, and the actual controlling shareholders of the company and its/their directors, supervisory board members and senior managers; directors, supervisory board members and senior managers of companies controlled by the issuer [appropriately adjusted in the 2007 Insider Trading Guidance Provisions, Article 6(2)(ii), to mean: "the controlling shareholders of the issuer or listed company, other companies controlled by the actual control party, and their directors, supervisory board members and senior management"]; people whose executive or staff position in the company provides access to inside information; CSRC staff and others who administer or regulate securities issuance and trading; and securities sponsors, underwriters, securities exchange personnel, securities registration personnel, and securities service institution personnel (which presumably includes lawyers and accountants).

A critical question is whether the Chinese characters "baokuo" for "include" or "including” in Article 74 means "including only" or "including without limitation." Increasingly, Chinese statutes follow contemporary Chinese language contractual drafting conventions, so that if the drafter seeks to codify the "including without limitation" idea, the character phrase "baokuo danbuxianyu" is used. That phrase is not employed in the 2006 statute. Accordingly, the effect of Article 74 is to limit the scope of insider trading defendants qua "persons with knowledge of inside information" to those persons or institutions listed in the article itself. In U.S. jurisprudential terms, the 2006 regime rejects the equal access theory while adhering to the Cady, Roberts/Chiarella line, with parties potentially liable identified in or via the Securities Law.

In direct tension with the 2006 PRC Securities Law declaration of fealty to classical insider trading doctrine at Article 74 are (i) the second prong of Article 73 (read in conjunction with a phrase in Article 76) and (ii) the significant delegation of regulatory authority to the CSRC in Article 74(vii):

The second prong of Article 73 along with one clause of Article 76 provides a separate "misappropriation" basis for insider trading. Those liable for insider trading sourced in misappropriation - described as the "those who have illegally procured inside information” (feifa huoqu neimu xinxi de ren) — are identified separately from, and do not have to be in the class of, "persons with knowledge of inside information" enumerated in 
Article 74. In U.S. jurisprudential terms, this tracks the 1997 United States v. O’Hagan ${ }^{24}$ innovation, creating an expanded basis of insider trading liability for traders who breach a fiduciary duty or other special relationship with the source of the inside information (per Chiarella the special duty or relationship must be with the trading counterparty). In such cases, the government only needs to demonstrate: (i) "illegal procurement" of information, (ii) that such information is "inside information", (iii) use of that inside information to trade, and (iv) trading of securities (of an issuer related in some way to the information). There is no requirement that the people who engage in misappropriation and trading be members of the Article 74 enumerated class of "persons with knowledge of inside information."

The last clause of 2006 PRC Securities Law Article 74 authorizes the CSRC to identify by regulation "others" aside from the traditional insiders enumerated in Article 74(i)-(vi) as "persons with knowledge of inside information." (There was no need to instruct the CSRC to augment the scope of defendants guilty of misappropriation because there is no defined class of "persons who have illegally procured inside information.") Given the strong focus on statutorily-enumerated insiders described above, the grant of regulatory authority to the CSRC in Article 74(vii) to widen the scope of "persons with knowledge of inside information" originally represented a very significant nod in the direction of loosening the under-inclusive list of insider trading defendants. It was also consistent with larger patterns in PRC legislative practice designed to allow a certain level of generality in law, while conferring significant discretion on administrative institutions.

In defining what the prohibited "use" of inside information is, the 2006 PRC Securities Law at Article 76 elaborates on the legal duties of (i) those "with knowledge of inside information", and (ii) those who have misappropriated inside information, duties which again seem to track, in part, the U.S.-style, disclose or abstain from trading rule: people in possession of inside information [relevant to specific] securities trading are prohibited from (i) purchasing or selling that company's securities, (ii) disclosing such information, or (iii) suggesting that others purchase or sell such securities, in each case at any time before such inside information is publicly disclosed. Article 76 of the 2006 PRC Securities Law - and specifically the clause prohibiting "suggesting that others purchase or sell such securities”- - therefore forms an additional basis in Chinese law for insider trading liability, or what other jurisdictions call "tipper” liability. This liability exists even where the defendant has not actually engaged in securities trading, though assuredly "used" inside information. Conversely, "tippees" are not subject to insider trading liability, at least insofar as they are not "persons with knowledge of inside

United States v. O’Hagan, 521 U.S. 642 (1997). 
information” per Article 74, or have not engaged in misappropriation of inside information under Articles 73 and 76.

The 2006 PRC Securities Law sets out a statutory definition of "inside information", while granting the CSRC authority to "recognize and confirm" (rending) other information that is inside information. In U.S. terms, the focus of these determinations is on the materiality (or "importance") of the information, and the degree to which it is public. The earliest definition of inside information under Chinese law came in 1993 at Article 5 of the SCSC Securities Fraud Measures, which stipulated that "inside information" consists of important (zhongda) non-public information known by traditional (status) insiders that might influence the price of securities traded in the market, but then also listed twenty-five other kinds of “important" information. Article 75 of the 2006 PRC Securities Law (largely tracking Article 69 of the 1999 PRC Securities Law) defines “inside information” broadly as: “... non-public information relevant to a company's business or financial affairs or which may have a major (zhongda) effect on the market price of that company's securities...” The Chinese character set "zhongda" translated here as "important" or "major" can be understood as the equivalent of "material." There is a much theoretical writing in the PRC on how to evaluate "importance" (zhongdaxing) or materiality, including a focus on standards objective (did the information in fact have a significant effect on price?) and subjective (would or did the information impact the decisions of a normal or reasonable investor?). ${ }^{25}$ There is no indication that these considerations are employed in actual enforcement.

Article 75 then lists items that are deemed to be inside information, including a cross-reference to the Securities Law Article 67(2) list of major events subject to U.S. SEC Form 8-K-like continuing disclosure. These items include: (i) the major (zhongda) events listed in Article 67(2) of the 2006 PRC Securities Law; (ii) company plans for distribution of dividends or increase of registered capital; (iii) major changes in the company's capital structure; (iv) major changes in the company's debt security/guaranties; (v) any single mortgage, sale or write-off of a major business asset of the company which exceeds $30 \%$ of the [value of] the asset; (vi) potential liability for major damages to be assumed under law as a result of behavior by a company's directors, supervisory board members, or senior management personnel; (vii) plans related to the acquisition of a listed company; and (viii) other important (zhongyao) information recognized and confirmed by the CSRC to have a significant effect (xuanzhu yinxiang) on the trading price of securities. The cross-reference to Article 67(2) of the 2006 PRC Securities Law imports the following items into the statutory definition of "inside

25 See for example: Ye Lin, Neimuxinxi De Falü Guanzhi [The Insider Trading Legal Regime], in ZHENGQUANFA JIAOCHENG [SECURITIES LAW] 314-5 (Ye Lin, Duan Wei, Wang Shihua \& Wang Huajie, eds., 2010). 
information": (i) a major change in a company’s business program or scope of business; (ii) a decision by the company regarding a major investment or asset disposition; (iii) conclusion by the company of an important (zhongyao) contract which may produce a significant (zhongyao) effect on the company's assets, liabilities, rights and interests or business results; (iv) the company's incurrence of a major debt or default on a significant (zhongda) debt that is past due; (v) a major deficit or losses incurred by the company ; (vi) a major change in the external conditions affecting production or business of the company; (vii) a change in the chairman of the board, or not less than one third of the directors or the manager of the company; (viii) a relatively significant (jiaoda) change in the holdings or control of shareholders who hold 5\% or more of the company's shares or the company's controlling shareholders; (ix) a decision by the company to reduce its registered capital, to merge, split, or dissolve, or to file bankruptcy; (x) [information relating to] major litigation involving the company, or voiding or declaration of noneffectiveness under law of a shareholders' meeting or board resolution; (xi) the establishment of a criminal investigation regarding the company or where judicial institutions have taken criminal enforcement measures against company directors, supervisory board members or senior management personnel; and (xii) other events stipulated in regulation by the CSRC. Only item (xi), criminal investigation or criminal enforcement against company officials, is new when compared to the same definitional clause in the 1999 PRC Securities Law.

The significant aspect of this statutory definition of inside information is the two bites of the apple given to the CSRC. First, the catch-all delegation of authority to the CSRC at Article 75(viii) allows the securities regulator to "recognize and confirm" other important information that has "a significant effect" on the trading price of securities. Second, the cross-reference in Article 75(i) to Article 67(2)(xii) of the 2006 PRC Securities Law gives the CSRC authority to stipulate in regulation other important (zhongda) events that can be imported into the definition of inside information. These two invitations, different in nature (one allows mere "recognition and confirmation", the other requires "stipulation in regulation”), are taken up with gusto in the 2007 Insider Trading Guidance Provisions described below.

At this stage of exposition, it is important to note two things about Article 75 and the definition of inside information: First, the statutory provisions give meaning to a specific defined term - "inside information" (neimu xinxi) - which is one of the elements necessary to make out insider trading liability under Articles 73, 74 and 76 of the 2006 PRC Securities Law. Second, neither Article 75 nor any other statutory provision alludes to a "price sensitive period." Each of these aspects will become important in the analysis of the 2007 Insider Trading Guidance Provisions, below, where the term "inside information" is a defined term used in a completely different architecture of the insider trading prohibition, and certain information becomes actionable "inside information" only when those in possession of it trade during a "price sensitive period." 
In sum, the statutory forms of Articles 73-76 of the 2006 PRC Securities Law - if undisturbed by the subsequent 2007 Insider Trading Guidance Provisions — create a system whereby only specifically-enumerated traders may have liability, a structure which can be both overbroad and under-inclusive.

It is potentially overbroad given the clear liability for innocent traders who are part of the Article 74 enumerated class and who trade while merely in possession of statutorily-defined inside information. One aspect of the over-broadness problem, at least with respect to liability for "persons with knowledge of inside information", is the failure of Chinese law to require any scienter or breach of duty on the part of those in possession of inside information who trade in the relevant securities before public disclosure of the information. (This problem does not apply to those who have misappropriated inside information under Articles 73 and 76, as their illegal procurement of inside information serves as an adequate proxy for fault or breach. Nor does this critique apply to the crime of insider trading under Article 231 of the Securities Law, Article 180 of the PRC Criminal Law and the 2012 Criminal Enforcement Explanation, which requires some showing of intentionality, interpreted as actual intent or recklessness. ${ }^{26}$ ) This raises the very strong possibility of strict liability for certain individuals who trade innocently in the relevant securities while they happen to be in possession of inside information. Professor Huang Hui of the Chinese University of Hong Kong has attempted to imply something less draconian than strict liability when writing about the analogous provisions of the 1999 PRC Securities Law. He understands the defendant's "knowledge that the possessed information is material and non-public" as a necessary element ${ }^{27}$ in establishing the case, and further divines a necessary causal link between the defendant insider's position and the acquisition of information, such that "persons with knowledge of inside information" are prohibited from trading only if they have access to the information because of their connection with the company whose securities are affected, by virtue of their office or profession. ${ }^{28}$ Professor Huang seem to conjure critical elements out of thin air: what he understands as a kind of breach of duty/scienter "lite" element, and what he later calls a "causal link" between trader status and "acquisition" (or even possession) of information. This effort to read some kind of intentionality requirement into the statute ultimately fails, ${ }^{29}$ and it is instead clear that - at least insofar

26 PRC Criminal Law, art. 14. Merely negligent behavior is only subject to criminal prosecution when the Criminal Law explicitly says so. Id., art. 15.

$27 \quad$ See Hui Huang, The Regulation of Insider Trading in China: A Critical Review and Proposals for Reform, 17 Austl. J. Corp. L. 281, 291-292 (2005).

28 Id. at 294-295.

29 As Professor Huang also recognizes: “This issue [“possession versus use”] is largely ignored in China... the issue deserves careful attention, particularly given the stiff liability of insider trading.” Id. at 292. 
as the statute is concerned-there is strict liability for the 2006 PRC Securities Law Article 74-enumerated persons who happen to possess inside information at the time they trade in securities of the company.

The structure is under-inclusive for traders not part of the Article 74 enumerated class but who trade on statutorily-defined "inside information", even apparently "tippers" alluded to in Article 76 (unless such "tippers" are also guilty of misappropriation). Two other kinds of transactions, punished by almost any coherent insider trading enforcement regime, fall outside of the Article 73-76 system: (i) “tippee” trading, and (ii) where an individual who acts as the financial advisor to an acquiring company trades in the stock of a listed target (defined here in short form as "tippees" and "M\&A advisors" respectively). In neither case (and other than tippees or M\&A advisors who have also engaged in misappropriation) is there any basis for the assertion of insider trading liability against such persons trading on non-public, material, information under the 2006 PRC Securities Law. “Tippees” are exculpated because Article 76 only prohibits "tipping” (although "tippees" would have liability if coincidentally members of the Article 74-enumerated class of persons with knowledge of inside information, or their gaining the tip involved some kind of misappropriation of inside information). "M\&A advisors" (again, unless guilty of misappropriation) are also not liable because they are outside of the enumerated class of traders listed in Article 74, as they are not employed at the company which issues the traded stock.

\section{b. The CSRC’s Parallel and Conflicting Enforcement Regime}

The CSRC evidently created the 2007 Insider Trading Guidance Provisions in response to the invitation at Article 74(vii) of the 2006 PRC Securities Law (and the more suitable invitation at Article 75(viii) of the same statute, calling for CSRC "recognition and confirmation" of important information that has a significant effect on securities' trading prices). However, the job was done very badly, with the CSRC issuing non-administrative regulatory norms of doubtful legality ${ }^{30}$ that far exceed the statutory invitation. ${ }^{31}$ While the Insider Trading Guidance Provisions do widen very significantly

30 See Enforcement Without Foundation, supra note 16. This problem is apparent in other key areas of PRC regulation and enforcement. See Wei Cui, What is the "Law" in Chinese Tax Administration? 19:1 Asia Pac. L. Rev. 75 (2011) (regarding the issuance and application of ultra vires tax “circulars” by the PRC Ministry of Finance and the State Taxation Administration, and the latter's 2010 regulation designed to legalize tax rule-making).

$31 \quad$ By their explicit terms, the Guidance Provisions apply to trading of publicly issued and stock exchange-listed securities (Article 4(2)), and are to be "referred to" with respect to insider trading identified at other State Council-approved trading 
the defined scope of “people with knowledge of inside information” under Article 74, they then go many steps further to recast entirely insider trading in China and create new and additional bases for liability, far beyond that ever contemplated in China's 2006 Securities Law. The result, in U.S. jurisprudential terms, is non-public guidance - not law or administrative regulation - that provides for a Texas Gulf Sulphur theory of liability targeting anyone simply in possession of inside information who trades. Recall that the 2006 PRC Securities Law provides for a much narrower version of liability, applicable only to specific insiders identified in, or pursuant to, the statute, plus what aspires to be liability connected to misappropriation.

How do the 2007 Guidance Provisions accomplish this wholesale restructuring of PRC insider trading law? Article 12 of the Insider Trading Guidance Provisions (under a Section IV entitled "The Recognition and Confirmation of Insider Trading Behavior") ignores entirely the statutory scheme and sets forth a brand new architecture establishing the elements of insider trading, as follows:

Article 12: Securities trading activity that conforms to the following conditions shall constitute insider trading:

(1) the person undertaking the behavior is an insider;

(2) the information involved is inside information;

(3) the subject person buys or sells related securities during the price sensitive period of the inside information, or suggests that other persons buy or sell related securities, or reveals the information.

This formulation is at substantial variance with, and goes far beyond, the insider trading regime as it is defined in Articles 73-76 of the 2006 PRC Securities Law described above.

The Insider Trading Guidance Provisions at Articles 5 and 6 create a new defined term, "insider" (neimuren), which term does not appear in the 2006 PRC Securities Law. The Securities Law never mentions, or addresses the liability of, "insiders", but only "persons with knowledge of inside information", people guilty of misappropriation, and either of the foregoing who tip others. The Insider Trading Guidance Provisions, authorized to elaborate the class of persons included in the category of "persons with knowledge of inside information", do exactly the opposite at Article 6(1) and reverse-

venues. This limitation does not amount to much, as all insider trading enforcement actions are with respect to securities traded on the Shanghai and Shenzhen exchanges (and might only be useful as a defense for state-owned enterprise insiders and political cadres illegally and personally trading in non-listed, non-tradable, shares in listed PRC issuers, whose actions bring other bases for liability). 
merge the 2006 PRC Securities Law Article 74(i)-(vi) statutory list of “persons with knowledge of inside information" into the Guidance Provisions-created category of "insiders." The statutorily-ungrounded definition of "insider" is then further expanded in Articles 6(2)-(5) of the Provisions to include:

- The issuer (as a "person with knowledge of inside information")

- The controlling shareholder of the issuer, entities controlled by the actual control party of the issuer, and their respective directors, supervisory board members and senior management (as "persons with knowledge of inside information”)

- Any party involved in a listed company’s merger, acquisition or reorganization and their relevant personnel (as "persons with knowledge of inside information”)

-Persons who gain inside information in the performance of their work (as "persons with knowledge of inside information”)

- The partners and spouses of those natural persons included in Article 74(i)-(vi) of the Securities Law (i.e., the statutorily-defined "persons with knowledge of inside information")

- The parents or children or other relatives of any natural persons included in the above categories who come into possession of inside information

-Those who employ illegal methods such as trickery, coaxing, eavesdropping, monitoring, secret trading, etc. to gain inside information

- Those who gain inside information through other channels

Finally, Article 5 of the Insider Trading Guidance Provisions stipulates that such insiders may be legal persons as well as natural persons. Perhaps most egregiously expansive in the new formulation is the substance of Article 6(5) of the Guidance Provisions, the last bullet above, which deems anyone "who gains inside information through other channels” to be an "insider” for enforcement purposes. This is tantamount to declaring that trading while in mere possession of inside information (and during a price sensitive period) is a basis for insider trading liability in the PRC.

As noted above, Article 75 of the 2006 PRC Securities Law defines “inside information" and lists items that are deemed to be inside information. The statute also delegates to the CSRC the power to "recognize and confirm" other important information that has "a significant effect on the trading price of securities." The CSRC's 2007 Insider Trading Guidance Provisions respond to this delegation, but in a way that looks past the statute. Most importantly, the Guidance Provisions define "inside information” not for the 2006 PRC Securities Law (and Articles 73,74 and 76 which invoke use of such information as an element to make out the breach), but instead under the Guidance Provisions, and specifically the new and independent invocation of "inside information" in the Article 12 prohibition set forth above. Thus, instead of using the Guidance Provisions to fill out the meaning of the statute, the Guidance Provisions use the statute to fill out, in part, the meaning of a newly employed term in the Provisions. 
Article 7 of the Provisions changes ever so slightly the general definition of "inside information" in the preamble to Article 75 of the Securities Law, stating that inside information under the Provisions means “... non-public ${ }^{32}$ information relevant to a company's business or financial affairs or which may have a major effect on the market price of $a$ company's securities...”. Compare this formulation with the Securities Law Article 75 language, which focuses on information that may have a "major effect on the market price of that (gai) company's securities." This very small difference may be designed to facilitate CSRC enforcement against defendants who trade in the securities other than firms where they are classical insiders, such as the insider trading M\&A advisors described above.

At Article 8, the Provisions then reverse-merge 2006 PRC Securities Law Article 67(2) (piggy-backing onto Article 67(2)(xii)'s delegation to the CSRC of all Form 8-Ktype events which have a "relatively significant" effect on the securities price), Article 75(ii)-(vii), and Article 75(viii)’s delegation of the power to determine "inside information" into the Provisions' own definition of "inside information”. Further, the Provisions at Article 8(5) declare simply that inside information under the same Guidance Provisions is "other important information that has a significant effect (xuanzhu yinxiang) on the trading price of securities" - which language tracks exactly the precise delegation made to the CSRC under Article 75(viii) of the 2006 PRC Securities Law. In conversational terms, the statute authorizes the regulator to "define $\mathrm{X}$ to include whatever

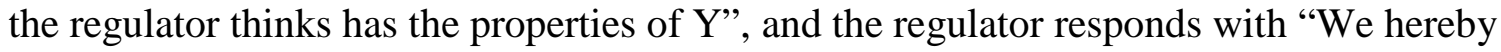
define $\mathrm{X}$ to include whatever we think has the properties of $\mathrm{Y}$ ”, without elaboration. In short, the Guidance Provisions do not sharpen or define the CSRC's enforcement power in any significant way, and instead offer somewhat tautological expressions of authority and coverage. Happily, the Guidance Provisions at Article 9 do state what information that has "a significant effect on trading prices of securities" means: in normal circumstances, information that immediately upon disclosure and for a specified period causes the company's trading price to depart significantly from the market index or the index for like issuers, or that causes significant volatility in the broad market index.

Finally, Article 10 of the 2007 Insider Trading Guidance Provisions injects a totally new concept into the determination of what "inside information" is, such that specific information becomes actionable only when those in possession of it trade securities during a "price sensitive period." That period is defined in the Insider Trading Guidance Provisions to extend from the time when the inside information begins to be constituted to the moment when the information no longer has an effect on securities

32 The meaning of "public" is defined at Article 11 of the Insider Trading Guidance Provisions. 
prices (the definition is further refined in the 2012 Criminal Enforcement Explanation with the elaboration of yet another new legal term with no statutory basis, "inside information sensitive period"). This new concept is the result of a drafting difference between the 2006 PRC Securities Law and the 2007 Insider Trading Guidance Provisions. As noted above, Article 76 of the Law states that people with knowledge of inside information relevant to specific securities are prohibited from doing certain things before such inside information is "publicly disclosed." Article 12(3) of the Guidance Provisions changes that prohibition to apply to a "price sensitive period" (jiage mingan qi), which is not bounded by the moment such information becomes "publicly disclosed." Instead, the CSRC Guidance Provisions extinguish traders' legal obligations at the moment when "the information no longer has an effect on securities prices" - a time very difficult for any trader in possession of inside information to determine with certainty.

In sum, the 2007 Insider Trading Guidance Provisions explode the bounds of the 2006 PRC Securities Law. Whereas under the 2006 Law only a narrowly-defined class of "persons with knowledge of inside information" or those who engaged in misappropriation (acting directly or as tippers) could be liable for specifically-defined insider trading, under the CSRC's 2007 Guidance Provisions any person simply in possession of information (and thus an "insider" under the Provisions) that is determined to be "inside information" who "purchases or sells relevant securities, or suggests that another purchase or sell such securities, or communicates such inside information” during a "price sensitive period" is liable for insider trading. ${ }^{33}$

The result is a kind of strict liability under the Insider Trading Guidance Provisions for anyone trading in securities when deemed to be in possession of inside information and during a price sensitive period. To be fair, the liability is not absolutely strict as the same Guidance Provisions introduce a scienter-like requirement - "whether or not [the defendant] knew or was informed of (zhicai) inside information - but only for (i) "the parents or children or other relatives of any natural persons" included in the expanded scope of "persons with knowledge of inside information" in the 2007 Guidance Provisions ${ }^{34}$ and (ii) "those who employ illegal methods such as trickery, coaxing,

33 It should be noted that the Provisions, at Article 19, provide diverse bases for exculpation, ranging from blanket exculpation (e.g., stock buy-backs or transactions pursuant to triggered mandatory offers) to knowledge defenses and even the broad discretion of the CSRC.

34 Limited to: the securities issuer; the controlling shareholder of the issuer, companies controlled by the actual control party of the issuer, and their respective directors, supervisory board members and senior management; any party involved in a listed company's merger, acquisition or reorganization and their relevant personnel; and persons who gain inside information in the performance of their work. 
eavesdropping, monitoring, secret trading, etc. to gain inside information;" and "those who gain inside information through other channels." 35 This will be cold comfort for the huge class of other potential defendants, for at the same time the 2007 Guidance Provisions make insider trading liability only stricter for (i) the "persons with knowledge of inside information” originally listed in the 2006 PRC Securities Law at Article74(i)(vi) and (ii) the expanded scope of such persons, reversing the burden of proof so that such defendants will be liable for insider trading during the price sensitive period unless "they have sufficient evidence to demonstrate that they did not know or were not informed of inside information."36

How do these major differences between the statute and CSRC enforcement "guidance" work out in potential application to culpable trading? Here I give two examples. First, "tippees” (as defined above) who are not guilty of misappropriation and who trade during the price sensitive period would be liable under the CSRC Insider Trading Guidance Provisions, although not under the 2006 PRC Securities Law. Likewise, M\&A advisors (as defined above) consulting for an acquirer and trading in the shares of a target company during a price sensitive period would also be liable for insider trading under the CSRC Guidance Provisions, but not under the Securities Law. To be very clear, the issue is not that the CSRC has broadened the scope of "persons with knowledge of inside information” under Article 74 of the 2006 PRC Securities Law, something that agency was perfectly entitled to do. Instead, the problem is that the CSRC has created a whole new class of defendants - outside of "persons with knowledge of inside information," and those guilty of misappropriation (acting directly or as "tippers") - called "insiders" who can now be exposed to serious liability if they trade during a price sensitive period with respect to any securities (i.e., not the securities of the company relevant to their status), and with a new burden of proof which almost assures their guilt (unless they can prove a negative, that they did not know or were not informed of the inside information).

Finally, insider trading prohibitions in the PRC are enforced through administrative and criminal penalties. There remains some question as to the grounds for a private right of action in damages for other market participants.

Article 202 of the 2006 PRC Securities Law provides the basis for administrative enforcement and penalties, which include: disposition of the illegally traded securities, confiscation of illegal proceeds, and the levy of administrative fines ranging from one to five times illegal proceeds. The Insider Trading Guidance Provisions, at Articles 21-23, describe how the CSRC calculates "proceeds." Articles 24 and 25 of the Provisions 
present guidelines for CSRC determination of the relative severity of administrative sanctions. (Provision is also made for penalizing traders who do not realize gains from illegal insider trading, or only de minimus gains.) Fines and warnings may also be levied on or directed at natural persons involved with insider trading by legal entities. Personnel from securities regulatory institutions who engage in insider trading are subject to the heaviest administrative penalties. Article 180 of the PRC Criminal Law (buttressed by the 2006 PRC Securities Law’s Article 231) provides for criminal penalties against insider trading, including imprisonment for up to ten years and criminal fines (one to five times illegal proceeds). As noted above, in May 2012 criminal enforcement of the insider trading prohibition was sharply narrowed with issuance of the Supreme People's Court and the Supreme People's Procuratorate joint Criminal Enforcement Explanation, which reasserts the 2006 PRC Securities Law limitation on "persons with knowledge of inside information" as only those listed in Article 74 of the statute and elaborates slightly on what constitutes misappropriation and tipping of inside information.

The grounds for a private civil action, difficult in any case given causation and reliance elements and the competence of China's developing judiciary, are a bit murkier under PRC law. Article 207 of the superseded 1999 PRC Securities Law referred to “civil damages” arising in connection with insider trading, but made no mention as to how any victim of a defendant's adjudicated insider trading might sue for such damages. There is a similar, if stronger, hint of a private claim at Article 76 of the 2006 PRC Securities Law, which holds: "Where investors have experienced losses from insider trading behavior, the [inside] traders should bear compensation liability in accordance with law.” (The same clause appears at Article 77 with respect to securities trading manipulation.) However, there is no further elaboration of, or legal basis for, a private civil claim in the 2006 PRC Securities Law, which means that Chinese victims of someone else's insider trading would have to rely on a private suit in tort (or "rights infringement” (qinquan) under the PRC system) or possibly contract. Any effort by PRC plaintiffs to make out such a claim would very likely be met with a denial by the Chinese judiciary because of the absence of a clear "legal basis" (falü yiju) in statute for the claim. As one authoritative PRC securities law specialist concludes, “... thus there is still no way to fully protect the compensation [rights] for investors who are harmed by insider trading behavior." 37

\section{IV.Enforcement Against Insider Trading Pursuant to Statute and “Guidance”}

In specific insider trading enforcement actions, the CSRC has generally conformed to its reputation for seriousness of purpose, technical competence, and independence. For instance, the agency is rapidly developing a kind of insider trading-

$37 \quad$ Ye, supra note 24, at 312 
specific “common law” addressing complex issues of legal presumption, burdens of proof, and scienter. ${ }^{38}$ Yet, from a higher level, the CSRC is engaging in enforcement behavior which is arguably extra-legal: for, regardless of the clear conflict between the two regulatory structures described in statute, on one hand (modified "classical" plus O’Hagen misappropriation), and internal agency "guidance”, on the other (Texas Gulf Sulphur or mere possession of material, non-public, information while trading), the CSRC is actively enforcing insider trading liability under the extremely broad theory promised by the defective 2007 Insider Trading Guidance Provisions, and in situations where the explicit terms of the 2006 PRC Securities Law do not provide for liability. PRC academics note this, ${ }^{39}$ and a glance at the most recent enforcement decisions posted on the CSRC website confirms the problem:

A 2011 enforcement decision ${ }^{40}$ shows how liberally the CSRC misapplies Article 74 of the PRC 2006 Securities Law, in that the defendant is pronounced "a person with knowledge of inside information" simply because he "participated in... [the reverse merger] related affairs." This is not the same thing provided for under Article 74(iv) ("persons who are able to obtain relevant inside information concerning the company by virtue of the position they hold in the company"), which is unavailable precisely because the defendant comes into possession of important information about a company - the target-different from the one he is employed at. Nor does the CSRC makes any effort to base his liability in the misappropriation prong of the statute. The CSRC is clearly relying upon the wider basis for insider trading liability provided in the 2007 Insider Trading Guidance Provisions.

38 See Wu \& Pu, supra note 7, at 374 (describing CSRC jurisprudence in 2009 regarding: burden of proof on trader's defense that alleged inside information was developed from independent analysis; definition of "knowing" (or should have known) inside information; liability for traders who engage in insider trading only to incur losses and thus have no proceeds from breach; and the evidentiary approach to use of proxy accounts for insider trading).

$39 \quad$ Ye, supra note 24, at 319 ("The [Insider Trading Guidance Provisions] clearly stipulate that where insider trading with respect to any exchange-issued or -listed securities is identified, the Guidance Provisions are to be applied. If insider trading is identified on any other State Council-approved securities exchange, enforcement is to be implemented with reference to the Guidance Provisions.”)

$40 \quad$ See Zhongguo Zhengjianhui Xingzheng Chufa Juedingshu (Liu Yang) [China Securities Regulatory Commission Administrative Punishment Decision (Liu Yang)] (2011) No. 24, issued June 14, 2011. 
In another 2011 enforcement action, ${ }^{41}$ the CSRC does not indicate how the defendant qualifies as one of the persons enumerated in Article 74 of the 2006 PRC Securities Law, concluding simply that he became a "person with knowledge of inside information." He is not identified as an officer or shareholder of the selling controlling shareholder of the issuer, although he is identified as the top executive of another entity which may be a shareholder of the issuer holding more than five percent of the issuer per Article 74(ii) of the Securities Law. Nowhere in the decision does the CSRC feel the need to articulate how this defendant qualifies as a "person with knowledge of inside information", or if he is guilty of misappropriation of the information, no doubt because they are relying upon the broader basis for insider trading liability provided for in the 2007 Insider Trading Guidance Provisions.

In a standard 2010 husband-wife/tipper-tippee case, ${ }^{42}$ the CSRC simply declares the husband/tipper to be a "person with knowledge of inside information" without tying his status to the enumerated persons under Article 74. Nor does the CSRC independently identify him as a person guilty of misappropriation under Articles 73 and 76. He may be a tipper of material, non-public, information, but because he is neither a "person with knowledge of inside information" nor guilty of misappropriation, technically he is not subject to the tipping prohibition under Article 76. Thus, as a person who has merely come into possession of inside information, it is unclear how he is an insider trading defendant under the 2006 PRC Securities Law, unless the CSRC is using the broad basis for enforcement provided for under the 2007 Insider Trading Guidance Provisions. Second, the wife is a tippee-trader of inside information, and again there is no connection between her possession of the information and any kind of misappropriation. She is therefore not an appropriate defendant under the 2006 PRC Securities Law, and the only way in which the CSRC can accomplish enforcement against her is via the 2007 Insider Trading Guidance Provisions.

There remains a question as to whether the PRC People's Procuratorate was or is using the extra-legal coverage of the Insider Trading Guidance Provisions to establish the elements of the crime of insider trading via Article 180 of the PRC Criminal Law, thereby resulting in the imprisonment of certain persons. The real picture of criminal enforcement of the insider trading prohibition and Article 180 of the Criminal Law is obscured for legal analysts because criminal judgments are not publicized or reasoned in

$41 \quad$ See Zhongguo Zhengjianhui Xingzheng Chufa Juedingshu (Lin Shiquan) [China Securities Regulatory Commission Administrative Punishment Decision (Lin Shiquan)] (2011) No. 26, issued June 29, 2011.

$42 \quad$ See Zhongguo Zhengjianhui Xingzheng Chufa Juedingshu (Jia Huazhang and Liu Rong) [China Securities Regulatory Commission Administrative Punishment Decision (Jia Huazhang and Liu Rong)] (2010) No. 53, issued Dec. 21, 2010. 
the way civil and administrative law cases increasingly are. Instead, criminal defendants are simply reported to be guilty of "insider trading" and then subject to criminal punishment. Given the CSRC's attitude towards extra-legal insider trading enforcement, it is not unreasonable to think that the People's Procuratorate - as advised by the expert agency charged with enforcement, the CSRC - has also used the defective Guidance Provisions in the criminal sphere. This is certainly the implication of the rather sudden release of the 2012 Criminal Enforcement Explanation, which strongly reasserts the primacy of the statutory architecture over the unbounded 2007 Insider Trading Guidance Provisions in respect of criminal prosecutions.

\section{Conclusion and Proposal for Amendment}

The foregoing analysis tells us that the CSRC has enforced the 2006 PRC Securities Law prohibitions on insider trading not in accordance with the narrow theory set out in the Securities Law itself, but pursuant to the very expansive theory that lives through the ultra vires 2007 Insider Trading Guidance Provisions. Using U.S. jurisprudence by analogy, it seems that stuck with a statutory scheme that looks like a loose assemblage of the Cady, Roberts/Chiarella fiduciary duty and O'Hagen misappropriation lines, the Chinese securities regulator nonetheless wields a stick that tracks the broad enforcement regime implied in Texas Gulf Sulphur. It is also highly likely that the PRC public prosecutor has used the defective Insider Trading Guidance Provisions as the sole basis for enforcement of the crime of insider trading in cases where the alleged behavior of defendants does not come within the scope of the 2006 PRC Securities Law and the PRC Criminal Law. If nothing else, examples of extra-legal enforcement in the administrative sphere demonstrate clear violations of the 1996 Law of the PRC on Administrative Punishments, which forbids the imposition of administrative punishments without a statutory basis, makes invalid administrative punishments imposed not in accordance with law, and forbids the imposition of administrative punishment under law other than in accordance with publicly-promulgated norms. Extralegal enforcement in the criminal sphere is only more problematic, and contrary to a number of key Chinese laws and policy statements, from the PRC Law on Legislation to the PRC Constitution.

Interestingly, the serious problem of illegality and mismatch regarding insider trading enforcement described in this paper does not pertain with respect to the separate prohibition against "securities trading manipulation" under Article 77 of the 2006 PRC Securities Law. For such manipulation, the CSRC is perfectly in compliance with the law in providing mere "guidance" for enforcement, ${ }^{43}$ because Article 77 is drafted at a

43 Which it did at the same time it issued the defective Insider Trading Guidance Provisions in 2007. 
high level of generality, Article 77(iv) provides a broad catch-all against "other methods" of manipulation with no specific required elements to make out "manipulation" (such as scienter, purchase or sale of securities, etc.), and the statute makes no affirmative delegation of regulatory power to the CSRC or any other agency. Accordingly, the CSRC is free under the statute to enforce against such manipulative trading in any way it determines, and without reference to any notified or universally applicable administrative law norm - something I argue it cannot do with respect to insider trading.

Some, noting the anemic enforcement against rampant insider trading in the Chinese capital markets and less attuned to legal niceties in a developing legal system, may see extra-legal and over-broad enforcement by the PRC securities regulator or the public prosecutor as a positive phenomenon. How else, other than by the most aggressive and far-reaching enforcement design and practice, can the Chinese regulator punish brazen violators whose virtually costless behavior only fuels the vicious circle that leads to ever-increasing insider trading and market manipulation? After all, they point out, many of the people made insider trading defendants are in fact guilty of trading on nonpublic, material, information, even if their behavior does not breach the narrowly-drawn statutory prohibition.

Others, even if they do not overly object to the legal infirmities of the CSRC Guidance Provisions-based enforcement regime, will recognize that the illegality of insider trading enforcement norms casts a significant shadow over the PRC securities regulator's ability to govern China's capital markets, and thereby ensure the perceived transparency and information symmetry critical to sustaining investor confidence and participation. Any successful legal challenge to administrative or criminal enforcement of insider trading prohibitions by defendants would constitute a body blow to the regulator's hard-earned reputation for competence, regulatory power, and technical sophistication, and confirm what many small investors already understand as the unlevel playing field characterizing China's "casino” markets. Moreover, it would contribute to the vicious circle whereby the apparent costs of engaging in insider trading are virtually nil, encouraging in turn expanded illegal activity going forward.

The way to solve this particular set of problems is to recast, in its entirety, the statutory insider trading prohibition set forth in the PRC Securities Law. Specifically, that means abandoning (again using U.S. jurisprudence by analogy) the current PRC scheme stitching together the Cady, Roberts/Chiarella fiduciary duty and O'Hagen misappropriation lines, and replacing it with a system very close to what the CSRC has tried to employ, albeit ultra vires and illegally, with the 2007 Insider Trading Guidance Provisions, or a system closely modeled on the European Union ("EU”) Market Abuse Directive of 2003 ("MAD”) and the United Kingdom's Financial Services and Markets Act of 2000 ("FSMA"), which ironically is based in the same theories supporting the Texas Gulf Sulphur decision rejected long ago by the U.S. Supreme Court (but which nonetheless survives in the U.S. 1934 Securities and Exchange Act Rule 14e-3) . 
Without going into too much detail in this paper concerning the mechanics of the EU and UK systems, suffice to say that both are rooted in the concept of what is variously called "equal access to information”, "parity of information” or "market egalitarianism”. Accordingly, the EU's MAD contains broad provisions that prohibit persons in possession of inside information from (i) dealing in the securities to which the information relates using inside information, (ii) disclosing inside information to third parties unless the disclosure is made in the normal course of employment, profession or duties, (iii) recommending or inducing other persons, on the basis of inside information, to trade. Similarly, the UK's FSMA, at Section 118(2), defines “market abuse” to include situations where a person who has inside information "deals or attempts to deal in a qualifying investment or related investment on the basis of inside information relating to the investment in question.” As can be seen clearly, both European regimes neglect to fetishize "fiduciary duty" and breach of those duties in the style of U.S. federal jurisprudence, and instead extend the prohibition against insider trading (or "market abuse") to anyone who, in the words of MAD, "possesses inside information while that person knows, or ought to have known, that it is inside information." 44 Stated succinctly, "insiders" subject to the insider trading prohibition in the EU and the UK is a broader class of persons who merely come into possession of inside information, and not the far narrower class of persons in the U.S. who have breached a duty either to the eventual trading counterparty or the source of the information (or their respective tippees). Indeed, as noted above, this is precisely the theory and system the CRSC has tried to impose in China via the 2007 Insider Trading Guidance Provisions, albeit in direct conflict with the statutory basis provided for in the 2006 PRC Securities Law.

If the PRC Securities Law, and specifically the provisions on insider trading, are amended to conform with the EU and UK systems, some might object that this puts too much power into the hands of the CSRC and (for criminal prosecutions) the PRC Supreme People's Procuratorate to enforce against, or prosecute, innocent, benign or legitimate market behavior, or behavior that does not injure other market participants or indeed enhances the information efficiency of the Chinese capital markets. These are the same sophisticated arguments often put forward in the U.S. discourse at any time defendants and market participants perceive an attempt to depart from the U.S.'s traditional adherence to its very narrow fiduciary duty and misappropriation-based theories of enforcement. The answer to these concerns is that China is very different from the U.S., and that the PRC's capital markets are at a very different stage of development. In the PRC, the problems are (i) under-enforcement of the insider trading prohibition arising, in part, from a dysfunctional statutory scheme, and (ii) a widely-

44 Directive 2003/6/EC of the European Parliament and of the Council of Jan. 28, 2003 on Insider Dealing and Market Manipulation (Market Abuse), 2003 O.J. (I. 96) 16 , art. 4. 
shared perception that the PRC Mainland markets are characterized by lack of transparency, informational asymmetry and large-scale, and unchecked, manipulation. Accordingly, any new scheme which elaborates and clarifies enforcement possibilities against insider trading (and general "market manipulation”) must be a net positive in the context of contemporary China. In my personal opinion then, a new insider trading prohibition written into China's amended Securities Law more closely modeled on the schemes described in the EU's MAD and the UK's FSMA, and underlying the U.S.'s exceptional Securities Exchange Act of 1934 Rule 14e-3, would be in China's national interest, and would further the healthy development of the PRC's domestic capital markets. 


\section{Appendix - Selected Statutory Provisions}

\section{PRC Securities Law}

Article 73. It is prohibited for those with knowledge of securities trading [related] inside information or those who have illegally procured inside information to use inside information in undertaking securities trading activities.

Article 74. Persons with knowledge of securities trading [related] inside information include:

(i) directors, supervisory board members, and senior managers of the issuer;

(ii) $5 \%$ or more shareholders of the company and its/their directors, supervisory board members and senior managers, and the actual controlling shareholders of the company and its/their directors, supervisory board members and senior managers;

(iii) directors, supervisory board members and senior managers of companies controlled by the issuer; ${ }^{45}$

(iv) people whose executive or staff position in the company provides access to inside information;

(v) Securities Regulatory Organ [CSRC] staff and others who pursuant to their legally stipulated duties administer or regulate securities issuance and trading;

(vi) relevant securities sponsors, underwriters, securities exchange personnel, securities registration and settlement personnel, and securities service institution personnel; and

(vii) other persons stipulated in regulation by the State Council Securities Regulatory Organ [the CSRC].

Article 75. Inside information means non-public information relevant to a company's business or financial affairs or which may have a major effect on the market price of that company's securities in the course of securities trading activities. The following information all constitutes inside

${ }^{45}$ Appropriately adjusted in Article 6(ii)(2) of the 2007 Insider Trading Guidance Provisions to mean: "the controlling shareholders of the issuer or listed company, other companies controlled by the actual control party, and their directors, supervisory board members and senior management.” 
information:... (viii) other important information recognized and confirmed by the State Council Securities Regulatory Organ [the CSRC] to have a significant effect on the trading price of securities.

Article 76. Those with knowledge of inside information related to securities trading and those who have illegally procured inside information may not, prior to public disclosure of the inside information, purchase or sell that company's securities, or disclose such information, or suggest that others purchase or sell such securities.... 


\section{Insider Trading Guidance Provisions}

Article 12. Securities trading activity that conforms to the following conditions shall constitute insider trading: (1) the person undertaking the behavior is an insider; (2) the information involved is inside information; and (3) the subject person buys or sells related securities during the price sensitive period of the inside information, or suggests that other persons buy or sell related securities, or [publicly] reveals the [inside] information. 